\title{
The Right of Denial in Implementing the Position of Notary (Analysis of the Constitutional Court Decision Number 16/PUU-XVIII/2020)
}

\author{
Retno Indrianita Pratiwi ${ }^{1}$ Benny Djaja* \\ ${ }^{1}$ Faculty of Law, Tarumanagara University, West Jakarta 11440, Indonesia \\ ${ }^{*}$ Corresponding author. Email: bennyd@fh.untar.ac.id
}

\begin{abstract}
Legal protection is needed by notaries, given the obligation embedded with the notarial profession so that contents of the deed are kept confidential. In the application for the decision of the Constitutional Court Decision Number 16/PUU-XVIII/2020, the Indonesian Prosecutors Association asked for Article 66 paragraph (1) The Regulation of Notary Profession a phrase insofar as implementation of the phrase "with the approval of the Notary Honorary Council" contradicts the spirit of the 1945 Constitution of the Republic of Indonesia. It is the purpose of this research to study and analyze the legal protection of the notaries' right of denial in carrying out his position related to the decision of the Constitutional Court Number 16/PUU$\mathrm{XVIII/2020.} \mathrm{The} \mathrm{method} \mathrm{used} \mathrm{in} \mathrm{this} \mathrm{research} \mathrm{is} \mathrm{normative} \mathrm{research} \mathrm{with} \mathrm{statutory} \mathrm{and} \mathrm{case} \mathrm{approaches.} \mathrm{It} \mathrm{can}$ be concluded that legal protection for notaries is ensured through the presence of Notary Honorary Council or MKN in conducting examination before deciding whether or not to grant law enforcers to right to access and take copies of the original deed (minuta) and/or to summon the relevant notary. If the Examining Panel deems that the notary in question has professionally carried out his duties in accordance with the statutory regulations and that there is no violation related to the making of deeds, it shall thereupon reject the notary summons submitted by the law enforcement bodies.
\end{abstract}

Keywords: Notary's right of denial, secrecy of notarial profession, authority of public officials, Notary Honorary Council

\section{INTRODUCTION}

The profession of Notary was born from the need of helping and serving people who need authentic written evidence regarding conditions, events or legal actions. The role of notary was only to record or write down certain legal act committed by the parties in the form of a deed. A notary writes of what happened i.e., what he saw and experienced to happen about the parties/actors, then further making adjustments to adhere to the formal requirements in making authentic deed before finally pouring it into the deed.

Pursuant Article 1 paragraph (1) of Law Number 2 of 2014 concerning Amendments to Law Number 30 of 2004 concerning the Profession of Notary, hereinafter referred to as The Regulation of Notary Profession, notary is "a public official endowed with the power to make authentic deeds as well as other powers as referred to in the laws and regulations." It can be concluded that a notary is a public official who has the authority to make authentic deeds.

In Article 1868 of the Indonesian Civil Code (ICC) which is the source of Article 1 The Regulation of Notary Profession, it is explained that an authentic deed is "...a deed which is made in the form/manner stipulated by law by the public official who is in power for certain purpose at the place where the deed was made." From the description of the article, it can be concluded that every person who carries out the profession as a notary is considered a public official, and as such, the duties of a notary in making authentic deeds are contained in Article 1868 of the ICC, which broadly fulfills three elements. as follows:

1. made in the form prescribed by law;

2. made by public officials;

3. created within the working area of said official.

The services offered by a notary are closely related to the trust given by the two parties, in which case it can be said that giving trust to a notary public means that the notary inevitably has the responsibility to keep said trust. This responsibility can be either legal or moral. [1]

The importance of the role of a notary in the society and the sheer amount of responsibility attached to his station requires certain extend of legal protection to be provided for the station of a notary in carrying out his/her duties. Legal protection is needed by notaries considering that 
there exists an obligation for notaries to maintain the confidentiality of the contents of deeds in accordance with the applicable law i.e., in Article 16 paragraph (1) letter $\mathrm{f}$ of the Regulation of Notary Profession, which states that in carrying out his/her office, notaries must "safeguard all matters relating to the contents of the deed that he makes as well as all information obtained to make such deed in accordance with the professional oath/pledge, unless otherwise stipulated by the laws."

Maintaining the confidentiality of all matters regarding deeds made by a notary is a must. This is based on the oath of office taken in accordance with the Regulation of Notary Profession. If this is violated, the Notary will be subject to criminal threat in accordance with the applicable law in Article 322 of the Criminal Code. Maintaining the deed's information made by the notary is defined as maintaining the confidentiality of the contents of the deed to the parties involved, including when the notary who made the deed is asked to provide information before a court hearing, the notary may use his obligation to keep information about the deed made by exercising the right of denial (verschoningsrecht). Based on the aforementioned considerations, notary public must be ensured, granted, and obtain protection in relation to the position he holds for the interests of the parties regarding the authentic deed he has made.

A notary is a citizen who holds the same position before the law as stated in the 1945 Constitution of the Unitary State of the Republic of Indonesia (hereinafter referred to as "the 1945 Constitution"), specifically Articles 27 paragraph (1) and 28D paragraph (1). Article 27 paragraph (1) of the 1945 Constitution states that, "All citizens shall have the same position in law and government and are obliged to uphold the law and government without exception." While Article 28D paragraph (1) of the 1945 Constitution explains that "Every person has the right of recognition, guarantees, protection, and certainty before a just law, and of equal treatment before the law".

According to Article 66 paragraph (1) of Law Number 2 of 2014 which contains the Amendment to Law Number 30 of 2004 concerning the Regulation of Notary Profession, the Notary Honorary Council (Majelis Kehormatan Notaris/MKN) is authorized -for the benefit of judicial due process, investigators, public prosecutors, or judgesto render approval or rejection of the request submitted to:

"a. take photocopies and/or letters related to the original deed (minuta) or Notary Protocol in the notary deposit; and

b. summon the Notary to be present at the examination related to the Notary Deed or Protocol under the Notary's supervision."

The Notary Honorary Council has the authority to grant approval to the Police, The Public Prosecutor and the Panel of Judges to examine the Notary. This regulation was only formed in 2016 which is regulated in the Regulation of the Minister of Law and Human Rights Number of 2016 concerning Trustees. This is a special right for a Notary as stated in the rules for implementing the mandate of Article 66A of Law 2/2014.
Article 1 number 1 of the Ministry of Law and Human Rights Number 7 Year 2016 is listed that: "The Notary Honorary Council is the body authorized to carry out the guidance of Notaries and has the obligation to give approval or rejection for the purposes of investigation and trial, to take photocopies of the original deed (minuta) and notary summons to attend. inspection in the Notary's warehouse". [2]

MKN as an institution consists of a Central Notary Honorary Council (Majelis Kehormatan Notaris Pusat/MKNP) and Regional Notary Honorary Councils (Majelis Kehormatan Notaris Wilayah/MKNW). The duties of MKNP are to carry out the guidance and supervision of MKNW and the tasks performed by MKNW. Meanwhile, the authority to approve or reject requests for approval of summons to a notary to attend an examination that will be carried out by law enforcement officials is the duty of MKNW.

This confirms that law enforcement officers can no longer simply summon notaries for questioning, but instead having to first obtain MKN approval for the purpose of investigation and judicial process to take photocopies of the original deeds (minuta) and summon Notaries for examinations concerning the deed or Notary Protocol. [3] In relation to the above, there is a decision by the Constitutional Court with decision Number 16/PUUXVIII/2020, in which the Indonesian Prosecutors' Association submitted an application for judicial review of Article 66 paragraph (1) of the Regulation of Notary Profession to the Constitutional Court (MK), because prosecutors cannot examine notaries without first obtaining the permission of the Notary Honorary Council (MKN).

Based on the aforementioned elaborations, the issue to be investigated in this research is concerning the legal protection of the notaries' right to denial in carrying out his position, particularly in relation to the Decision of the Constitutional Court Number 16/PUU-XVIII/2020. The purpose of this research is to study and analyze the legal protection of the notaries' right of denial in carrying out his position in relation to the Constitutional Court Decision Number 16/PUU-XVIII/2020. The theoretical benefits of this research are expected to contribute to the body of materials ultimately for the development of knowledge in the field of notary offices in Indonesia. It is also hoped that it can provide practical input for various relevant stakeholders, including academics, legal practitioners, and members of the public or parties having interests in the certainty of legal protection provided for this particular right of notarial profession.

\section{METHODS}

This research used normative research method, which is carried out in a deductive manner, starting with an analysis of the articles in the laws and regulations that govern the above problems. This research is expected to be able to provide a detailed, systematic, and comprehensive description of all matters relating to a notary's right of denial. Researchers used mainly a statutory approach 
(Statue Approach), carried out by understanding the various laws and regulations related to the legal problem being handled, as well as the case approach, which is carried out by examining the cases relevant with the legal problem being studied. Researchers used varied types of legal materials in the form of secondary data, namely primary legal materials, secondary legal materials, and tertiary legal materials.

Primary legal materials are obtained from binding sources such as laws and regulations which include Law Number 2 of 2014 concerning Amendments to Law Number 30 of 2004 concerning the Position of Notary Public. Secondary legal materials are materials that provide information or other matters relating to the content of the main material sources and their implementation and can help analyze and understand primary legal materials. The legal material collection techniques used in this study were obtained from tracing through library research activities, namely collecting various legal materials, both in the form of books, literature, statutory regulations, notary deeds, official documents, previous research results, reports, papers, and other sources. The technique of collecting legal materials used in this research is to read critically and analytically then find the problems and legal issues to be studied and collect all the information that is related to the problem concerned, then select relevant and essential information. The analysis of legal materials used is qualitative analysis, which is to discuss the legal materials that have been obtained by referring to existing theoretical foundations. [4]

\section{FINDINGS AND DISCUSSIONS}

\subsection{Constitutional Court Decision Number 16/ PUU-XVIII/2020}

In the Decision of the Constitutional Court Number 16/PUU-XVIII/2020, the Petitioner is the Association of Indonesian Prosecutors represented by Setia Untung Arimuladi, S.H., M.Hum as the Chairperson of PJI as Petitioner I, Olivia Sembiring, S.H., M.H as Petitioner II, Dr. Asep N. Mulyana, S.H., M.Hum as Petitioner III, Dr. Reda Manthovani, SH, LLM as applicant IV, and R. Narendra Jatna, SH, LLM as petitioner V, who feel their constitutional rights have been impaired by the phrase "with the approval of the Notary Honorary Council" in Article 66 paragraph (1) of the Regulation of Notary Profession.

This places the Notary Honorary Council as the absolute and final authority to approve or otherwise deny summons extended to certain notaries to attend certain case examination. This right unables investigators, public prosecutors, and judges to take further legal remedies with regards to certain deeds made by or before a public notary. So the petitioners demanded that the Constitutional Court declare Article 66 paragraph (1) of the Regulation Of Notary Profession null and without binding legal force insofar as the phrase/sentence "with the approval of the
Notary Honorary Council" is implemented in contradiction to the 1945 Constitution.

In its legal considerations, the Court is of the opinion that Petitioner I, although is an association that brings together all prosecutors in Indonesia, is not a legal subject referred to in Article 66 paragraph (1) of the Regulation of Notary Profession. Especially in relation to the law enforcement process, which is the authority of the prosecutor, one among those regulated in Article 66 paragraph (1) of the The Regulation of Notary Profession, only investigators, public prosecutors, and judges are entitled to demand investigative measures against certain notarial deeds or otherwise the notary in question. Therefore, according to the Court, in the Petition a quo, Petitioner I does not have a legal standing as a Petitioner.

Meanwhile Petitioner II, who is an Indonesian citizen who works as a Prosecutor, is experiencing legal uncertainty. This is guaranteed by Article 28D paragraph (1) of the 1945 Constitution due to protracted and obstructed legal process faced by Petitioner II in his role as Public Prosecutor in a criminal case involving the provision of false information in the making of authentic deed by suspects Johanes Narnius Lunek and friends. According to the Court, in the petition a quo, Petitioner II has a legal standing as the applicant, meanwhile Petitioners III, IV, and $\mathrm{V}$ are not entitled to the same legal standing. Therefore, it was concluded that they cannot submit together the petition a quo since, the Court has not found that the Petitioner is an investigator in a special criminal case or otherwise a public prosecutor.

This is stated and in accordance with Article 66 paragraph (1) of The Regulation of Notary Profession which regulates the authority of investigators, public prosecutors, and judges in having access to the original (minuta) of related deeds, and to summon a notary to attend an examination related to the deed or protocol of the notary concerned. is in the notary's warehouse, the prosecutor associated with the authority is a prosecutor in his capacity as an investigator or public prosecutor, because prosecutors do not always function as investigators or public prosecutors.

If we take a look back at the previous related decision constituting the body of jurisprudence, namely the Decision of the Constitutional Court Number 22/PUUXVII/2019, we would figure that the basis for the constitutional examination is Article 27 paragraph (1) of the 1945 Constitution. Article 28D paragraph (1) and Article 28G paragraph (1) of the 1945 Constitution. While the petition a quo uses as the basis for examination Article 1 paragraph (3), Article 27 paragraph (1), Article 28D paragraph (1) and Article 28I paragraph (1) of the 1945 Constitution.

However, after the Court read the two petitions in question more carefully, the constitutionality issue of the problem of Article 66 paragraph (1) of the Regulation of Notary Profession in the $a$ quo petition was found to be the same as the constitutionality issue in the Constitutional Court Decision Number 22/PUU-XVII/2019.

Thus, although the basis and reasons presented to the Court for constitutional examination are different so that the $a$ quo petition can pass the submission requirements, due to 
the same constitutionality issue, namely regarding the approval of MKN to take a copy of the Minutes of Deed and/or related letters and to summon the Notary to be present at the meeting. examination relating to deeds or notary protocols that are in the notary's custody, then the Court's consideration in examining Article 66 paragraph (1) The Regulation of Notary Profession in the Constitutional Court Decision Number 22/PUU-XVII/2019 referred to mutatis mutandis also applies to the a quo petition. [5]

\subsection{Legal Protection for the Obligations of Notary Public Related to the Constitutional Court Decision Number 16/PUU-XVIII/2020}

Notaries have the obligation to make evidence in the form of an authentic deed, where this authentic deed contains the wishes of the parties who appear before the notary. In its submission, the Petitioners surmised that Article 66 paragraph (1) of the Regulation of Notary Profession goes against the spirit of Article 1 paragraph (3), Article 27 paragraph (1), Article 28D paragraph (1), and Article 28I paragraph (1) of the 1945 Constitution, and therefore demanded that it be nullified.

However, after the Court read carefully the two petitions in question, it turned out that the constitutionality problem of Article 66 paragraph (1) of the Regulation of Notary Profession in the a quo petition was the same as the constitutionality issue brought up previously in the Constitutional Court Decision Number 22/PUU-XVII/ 2019.

It can be interpreted, although the basis and reasons for the testing used are not the same, which results in the a quo petition being submitted, due to the same constitutional problems, namely regarding the authority endowed to MKN to weigh and decide on whether to give approval or rejection to certain law enforcers' request to take a photocopy of certain deed(s) and/or related letters, and to summon the notary concerned to come to investigative meetings. The examination related to the deeds or notary protocols that are under the supervision of a notary and considerations of the Court in examining Article 66 paragraph (1) of the Regulation of Notary Profession are then referred to and cited in the Constitutional Court Decision Number 22/PUU-XVII/2019 to be applied mutatis mutandis in the petition a quo.

In making an authentic deed, there are 3 (three) groups of legal subjects, namely the parties concerned, the mandatory witnesses, and the notary himself. In this arrangement, the Notary is not a party in making the deed, but rather serves only as an official acting due to his/her legally provided authority to make an authentic deed based on the wishes of the parties [6].

Notaries must uphold the principle of balance between the rights and obligations of the parties before the Notary. This is based on Article 16 paragraph (1) letter a of the Regulation of Notary Profession, which obliges a notary to act at all times with the protection of the interests of the parties in mind. Notaries must be of good understanding as he is concerned with the wishes of all parties so that the interests of all parties are accommodated adequately as well as maintained proportionally, which is then manifested in the notarial deed produced. In addition, a Notary is obliged to provide his services in accordance with the provisions of Article 16 paragraph (1) letter d of the Regulation of Notary Profession, unless there is a legitimate reason for refusing it.

Before taking the office to carry out his duties, a notary as a public official is obliged to take an oath/pledge as stated in Article 4 paragraph (2) of the The Regulation of Notary Profession which reads: "I swear/pledge that I will obey and be loyal to the Republic of Indonesia, Pancasila and the 1945 Constitution of the Republic of Indonesia, the Law on the Profession of Notary Public, and other laws and regulations. That I will carry out my position with trust, honesty, thoroughness, independence, and impartiality. That I will maintain my attitude, behavior, and will carry out my obligations in accordance with the professional code of ethics, honor, dignity, and my responsibility as a notary. That I will keep the contents of the deed and information obtained in the exercise of my office a secret, that I can be appointed in this position, either directly or indirectly, under whatever name or pretext, never and will not give or promise anything to anyone."

Mostly in a legal case, a notary is required to attend trials and provide testimonies as a witness, but it is also possible for a notary to be the perpetrator as evident in several cases. As a witness for the settlement of criminal and civil cases, the presence and information given by the witness is considered to have helped in the settlement of the case.

When summoning a notary to serve as a witness, especially in criminal proceedings, the law enforcement officials must first obtain the approval of the Notary Honorary Council. This aims to provide legal protection for notaries in carrying out their job. The protection provided is related to the intention of maintaining the balance between the notarial obligation of keeping the confidentiality of deeds, and the interests of law enforcers in carrying out their duties as confirmed in the provisions of Article 66 of the Regulation of Notary Profession.

According to Satjipto Rahardjo, legal protection can be interpreted as an effort to protect someone by giving him the authority to act in his interest. [7] In the context of the Decision of the Constitutional Court Number 16/PUUXVIII/2020, the Indonesian Prosecutors Association deems that the legal protection as provided by their constitutional rights have been impaired by the implementation of the phrase "...with the approval of the Notary Honorary Council" contained in Article 66 paragraph (1) of the Regulation of Notary Profession. This particular article has at times unabled the investigators, public prosecutors, and judges to undertake further legal process in the attempt to secure remedies for the parties suffering losses as the result of the making of certain deeds.

Since the enactment of Law Number 2 of 2014 concerning Amendments to Law Number 30 of 2004 concerning the Regulation of Notary Profession, the Notary Honorary 
Council has been established along with its designated duties and functions, terms and procedures for appointment and dismissal, organizational structure, work procedures, and budget as regulated by Regulation of the Minister of Law and Human Rights Number 7 of 2016 concerning Notary Honorary Council.

In carrying out the coaching function, the Minister forms MKN which elements consist of notaries, government officials, and experts or academics. In carrying out its function as a legal protection agency, MKN has the powers as stated in Article 66 paragraph (1) of the Regulation of Notary Profession. In relation to this authority, previously it was the authority of the Regional Supervisory Council, as regulated in Article 66 of the Regulation of Notary Profession, which states that taking photocopies of deeds and summoning notary for legal inquiries are permissible in the interests of judicial due process, with the investigators, public prosecutors, or judges first obtaining the permission of the Regional Supervisory Council. the following transfer of some authority from MPD to MKN does not mean that MPD is no longer functioning since there are many other powers that are still within the authority of the MPD.

The existence of the institution of MKN is to "replace" the role of the MPD in approving or rejecting the notary's summons and the request of law enforcers to take photocopies of Notary protocols as submitted by investigators, public prosecutors, and/or judges. MKN is therefore an independent decision-making body that has the duty and obligation to provide guidance and supervision in order to strengthen the notary institution in enforcing the Regulation of Notary Profession for everyone who carries out the position as a Notary.

If the petition in the Decision of the Constitutional Court Number 16/PUU-XVIII/2020 regarding the phrase "with the approval of the Notary Honorary Council" in Article 66 paragraph (1) of the Regulation of Notary Profession is approved to be nullified, it will create the problem of the absence of MKN's role in developing notaries, especially in supervising the implementation of notarial obligations, that is, in keeping the secrecy of all matters relating to the deed which they have drawn up as well as all information obtained, which is used to make the deed in accordance with the oath/pledge of office. The role of the Notary Honorary Council regarding the summons of a Notary in criminal case examination is as follows:

1. The Notary Honorary Council has the authority to grant temporary approval to law enforcers.

Based on Article 12 of the Regulation of the Ministry of Law and Human Rights Number 7 of 2016 concerning the Notary Honorary Council, in carrying out its duties the Notary Honorary Council is assisted by the Examination Council and the Secretariat of the Notary Honorary Council. As explained in Article 27 of said Regulation, the approval of law enforcers in summoning notaries related to criminal case examination is carried out in the event that there is an alleged criminal act related to the original deed (minuta), the right to sue based on the provisions concerning expiration in the legislation in the field of criminal law, denial of the validity of the signatures of one or more parties, the alleged reduction or addition of the minimum deeds, and the suspicion that the Notary made a postponement of the date (antidatum).

2. The Notary Honorary Council conducts an examination hearing with the notary before giving approval or rejection to the law enforcers. In conducting the examination of the Notary Public, the Chairman of the Regional Notary Honorary Council forms an Examining Council consisting of 3 (three) persons who are members of the Council.

Summons extended to notaries shall be made by means of a letter signed by the Chairman of the Regional Honorary Council. The notary must be present to fulfill the summons of the Examining Council and may not be represented. In the event that the Notary is absent after being summoned legally and properly for 2 (two) times consecutively, the Examining Panel may make a decision on the request of the investigator, public prosecutor, or judge.

However, if the Notary is deemed by the Examining Panel to have performed its duties in accordance with what is ordered and regulated by statutory regulations and it is deemed that there is no violation in carrying out his duties related to the making of the deed, the Examining Panel shall rightly reject the request for notary summons that has been submitted. [8]

3. The Notary Honorary Council can accompany the Notary in the process of examining a criminal case. Assistance provided by the Notary Honorary Council is passive in nature, that is, it only gives confidence to the Notary who is accompanying it so that the Notary is confident and confident when dealing with law enforcement officials.

As a form of legal protection for Notaries in carrying out occupational secrets, in general it has been regulated in general regulations, as stated in the following statutory provisions:

1. Article 1909 paragraph (2) point 3e of the ICC, which reads: "Anyone who because of his position, job or position according to the law is obliged to keep something secret, but only solely regarding matters whose knowledge is entrusted to him as such."

2. Article 146 paragraph (1) point $3 e$ of Herzien Inlandsch Reglement (HIR), which reads: "All persons who because of their legal position or position are obliged to keep secret positions; but solely on such matters which are entrusted to him."

3. Article 277 paragraph (1) of HIR, which reads: "Persons, who are obliged to keep secrets because of their position, occupation or legal position can ask to resign from testifying; but only of that which was known and entrusted to him."

4. Article 170 paragraph (1) of the Criminal Procedure Code, which reads: "Those who because of their work, dignity or position are obliged to keep secrets, can ask to be exempted from the obligation to testify as witnesses, namely about matters entrusted to them." 
The legal protection provided for notaries in keeping the secrecy expected of notary offices in addition to have been generally regulated has also been specifically regulated in Article 17 paragraph (1) and (2) of Law No. 48 Year 2009 concerning Judicial Power, which reads:

"1. The party being tried has the right to deny the judge who hears his case.

2. The right to deny as referred to in paragraph (1) is the right of a person being tried to file an objection accompanied by the reasons before a judge hearing the case."

The secrecy of the profession itself according to Viswandro's Dictionary of Legal Terms is something inherent to the position and therefore should not be known by the larger public.[9] That means, even during the process of investigation, prosecution, or examination at trials, a notary has the right -which at the same time is equally his obligation by law- to keep the contents of the deed as well as all information obtained in its making confidential and therefore to deny any demand to disclose information he considers as confidential pertaining to the duty of his station. This is in accordance with the regulations in Article 16 paragraph (1) letter $\mathrm{f}$ of the Regulation of Notary Profession.

In Article 54 paragraph (1) The Regulation of Notary Profession that a Notary can give, show, or notify the contents of the deed, grosse of deed, copy of deed, or excerpt of deed, to any parties with direct interest in the deed, among others the heirs, or other persons who have obtained the rights, unless otherwise stipulated by the body of laws and regulations. Apart from the interests of the aforementioned parties, a notary in carrying his notarial oath must strictly maintain the confidentiality of the contents of the deed as well as the information he obtained in the exercise of his position.

The notaries' right to denial is both a legal protection mechanism provided for the notary and a means of protection utilized for the interest of the parties when the notary is asked for information by the legal enforcement apparatus to confirm or otherwise repel any suspicions against the notary concerned. The summoning shall be duly carried out in the following circumstances:

1. The court summons a particular notary to testify regarding the deed made by or before him. This is related to the implementation of notary duties based on Law No. 30 Year 2004 or statutory regulations.

2. Certain notary is summoned by investigators to testify as witnesses relating to certain deeds drawn up by or before him or relating to the implementation of the duties of a notary under Law No. 30 Year 2004 or statutory regulations.

3. The notary concerned is summoned by MPN, MKNW, or MKN to provide information or explanations relating to deeds drawn up by/before them or related to the implementation of the duties of a notary based on Law Number 30 Years 2004 or Law Number 2 Year 2014 on a public report, or summoned by MKNW or by MKN on behalf of an investigator, prosecutor's or judge's request to provide information or explanation relating to deeds made by / before him or related to the implementation of the duties of a notary under Law Number 30 Year 2004 or Law Number 2 Year 2014 [10]

The notary wishing to exercise the right of denial must make an application letter to the judge who hears and/or examines that the notary will exercise his memory right. After receiving the petition, the judge will decide to reject or grant the application for the use of the notaries' right of denial, so that if it is granted, the notary does not need to testify. A notary who is examined as a witness or provides information in the process of investigation can use his or her duty of denial through a direct statement rendered by the Notary, which is then recorded in the minutes of investigation. This procedure is imperative, which means that it is mandatory to use it when an investigation is carried out against a notary. [11]

\section{CONCLUSIONS AND SUGGESTION}

\subsection{Conclusions}

One of the legal protections made available for notaries is through the presence of $\mathrm{MKN}$ in conducting internal professional examination before deciding to take a photocopy of the original deed (minuta).

If the Examining Panel considers that the Notary Public in question has carried out his tasks in accordance with the laws and regulations and it is deemed that there is no violation in carrying out the duties related to the making of the deed, the Examining Panel shall reject the request submitted for the summons of the notary in question.

In the event that the notary is indicated to have committed a criminal act, he/she will be obliged to participate in providing information in an effort to obtain the truth for the sake of the continuity of the public interest of the State of Indonesia in accordance with Article 170 paragraph (2) of the Criminal Procedure Code. Regarding the Decision of the Constitutional Court Number 16/PUU-XVIII/2020, the right to denial is a legal protection for the Notary and is also a protection for the parties used when the Notary is asked for information regarding the legal apparatus' suspicion of the Notary concerned.

\subsection{Suggestions}

1. In view of the notary's responsibility in carrying out his obligation to keep the contents of deeds confidential, it is necessary to establish specific implementing regulations to provide the necessary legal protection to notaries in carrying out protective measures for any occupational secrets.

2. Notaries in carrying out their duties and positions must be more careful in making deeds so as to minimize the possibility of errors that may cause harm to the parties in the deed. 


\section{ACKNOWLEDGMENT}

Thanks to the Head of the Faculty of Law, Tarumanagara University, who has provided the opportunity and support to write this journal, and also thanks to those who have helped in writing this journal.

\section{REFERENCES}

[1] Topan Adiya Putra, (2016) "Tanggung Jawab Dan Tanggung Gugat Notaris Atas Minuta Akta Yang Hilang Atau Rusak", Surabaya: Tesis, Magister Kenotariatan, Universitas Narotama.

[2] Peraturan Menteri Hukum Dan Hak Asasi Manusia Republik Indonesia Nomor 7 Tahun 2016 tentang Majelis Kehormatan Notaris.

[3] Wilma Silalahi, Konstitusionalitas Pemeriksaan Dan Pemanggilan Notaris Melalui Majelis Kehormatan Notaris, 2020.

[4] Achmad, Mukti Fajar dan Yulianto, Dualisme Penelitian Hukum Normatif dan Empiris, Yogyakarta: Pustaka Belajar, 2010.

[5] Putusan Mahkamah Konstitusi Nomor 16/PUUXVIII/2020 tentang Pengujian Undang-Undang Nomor 30 Tahun 2004 tentang Jabatan Notaris terhadap Undang-Undang Dasar Negara Republik Indonesia Tahun 1945.

[6] Tuti Irawati, Analisa Tanggung Jawab Notaris Sebagai Pejabat Umum Terhadap Akta Yang Dibuat Dan Berindikasi Perbuatan Pidana, Tesis, Juli, 2010.

[7] Satjipto Rahardjo, Sisi Sisi Lain dari Hukum Indonesia, Jakarta: Kompas, 2003.

[8] Hermawan Udi, Kewenangan Majelis Kehormatan Notaris Wilayah Dalam Memberikan Persetujuan Terhadap Pemanggilan Notaris Oleh Penegak Hukum, Jurnal Akta, Vol. 4 No. 3, 2017.

[9] Viswandro, Kamus Istilah Hukum Sumber Rujukan Peristilahan Hukum, Yogyakarta: Pustaka Yustisia, 2014.

[10] Habib Adjie dan Muhammad Hafidh, Memahami Majelis Kehormatan Notaris (MKN), Semarang: Sinergi Offset, 2016.
[11] Made Pramanaditya Widiada, Eksistensi Kehormatan Notaris Dalam Perlindungan Hukum Terhadap Notaris, Jurnal Ilmu Hukum, Vol 4, No.3, 2016. 